Hope, T. (2008). 'The first casualty: evidence and governance in a war against

crime'. In P. Carlen (Ed.) Imaginary Penalities. Cullompton, Devon: Willan. ISNB

978-1-84392-375-6; pp. 45-63. (C) The editor and contributors.

\title{
THE FIRST CASUALTY: evidence and governance in a war against crime
}

\section{Tim Hope}

Among the calamities of war may be jointly numbered the diminution of the love of truth, by the falsehoods which interest dictates and credulity encourages.

Samuel Johnson, 1758.

Pat Carlen's concept of imaginary penality draws our attention to how artificially constructed rationales for the criminal justice system are supplanting the substantive and symbolic justifications that have hitherto featured in public discourse. Whereas the latter are widely understood, and amenable to empirical and moral challenge, these imaginary penalities create aims and objectives that bind criminal justice agencies into performance criteria that, despite their commonsensical appearance are, for the most part, unattainable and immeasurable. Yet they also provide governments with popular political mandates. The assertion that government initiative alone can reduce crime and thereby create community safety - thus rendering re-electable those governments that claim to have done it - is one such imaginary. The task for an incumbent government, then, becomes that of sustaining these penalities in the popular imagination, which may mean a greater readiness to resist contrary claims and sceptical challenge, particularly if the stakes are high, and there is an opportunity to get away with it.

For the 'New Labour' Government of the United Kingdom, the happy circumstance of having enunciated particularly strident and ambitious crime reduction plans whilst in opposition, winning a landslide election in 1997 (in part on the basis of such promises - Downes and Morgan, 2002), promulgating programmes and legislation once in office (Home Office, 1999), and thence presiding over year-on-year reductions in the official indicators of crime, must have seemed sufficiently incontrovertible evidence. Yet, except on a few occasions (some of which will be recounted here), Ministers have been reticent about claiming success; let alone crowing over their achievements. One explanation is that they have been content to let the record 'speak for itself'. In appealing to the popular imagination, the causal logic seems inescapable: government says it is going to reduce crime; it says it is undertaking activities that it claims will reduce crime; the official record shows crime going down; ergo a tremendous government achievement. And why should we demur? Governments have great assets as purveyors of truth: they tend to have a political and resource-based monopoly over the generation of the relevant information; and the capacity to scrutinise the evidence requires not only access to government data but possession of expertise and inside knowledge that is not normally accessible to the general public. Perforce, the public is obliged to trust the reliability and validity of their Government's claims, with the democratic compact between governments and governed as its sole guarantor.

Such trust is presumably what the then recently-appointed Home Office Minister Hazel Blears, MP must have relied upon when she announced in July 2003 a "...tremendous impact on burglary rates", reported in a Press Release headed 
Hope, T. (2008). 'The first casualty: evidence and governance in a war against crime'. In P. Carlen (Ed.) Imaginary Penalities. Cullompton, Devon: Willan. ISNB 978-1-84392-375-6; pp. 45-63. (C) The editor and contributors.

"Groundbreaking Projects Crack Burglary" (Home Office Press Release 177/2003, 25 Jun 2003 10:45). The Minister was drawing upon “...early findings on burglary reduction" from its Reducing Burglary Initiative (RBI). The RBI comprised a major part of the New Labour Government's “...crusade ( sic) against crime” preached by the then Home Secretary (the Rt. Hon. Jack Straw, MP) in his encyclical foreword to the Government's Crime Reduction Strategy (Home Office, 1999). The RBI itself was a flagship component of the Government's Crime Reduction Programme (CRP): "...the most ambitious and innovative programme for tackling crime so far attempted in the western developed world." (Homel et al., 2004: 1). According to officials, the CRP was intended to find long-term, sustained reductions in crime through implementing "what works", promoting innovation into mainstream practice, generating significant improvement in the crime reduction knowledge base, and delivering real savings through crime reduction and improved delivery (ibid.). As the Home Secretary told Parliament in July 1998, the CRP was also unprecedented in being inspired by criminological research evidence (Goldblatt and Lewis, 1998); while HM Treasury had also required the Home Office to conduct a large-scale programme of independent, social scientific evaluation of the CRP (Homel, et al., 2004).

Evidence from social scientific research was thus to play an important role in the CRP. The evidence cited by the Minister in her announcement drew upon an accompanying Home Office research report Findings 204 (Kodz and Pease, 2003). This was based on Home Office officials' analysis of data collected by consortia of university-based researchers under contract to evaluate the impact of local crime prevention projects comprising a first-phase of the RBI. In my capacity as coordinator of one such consortium (Hope, et al., 2004), I had been sent a draft copy of Findings 204 prior to publication (none of our consortium had been involved in any of the data analysis presented therein). I expressed considerable misgivings about its methodology, concluding "...I would rather you did not publish these Findings in this form...failing that, please note that...if asked publicly, I shall feel compelled to disassociate myself from it" (letter, 16 May 2003) ${ }^{1}$. Whether coincidence or not, Findings 204 was published while the British Society of Criminology was holding its Annual Conference at the University of Wales, Bangor; and I did disassociate myself when it was presented by Home Office officials at a panel which we shared in the company of my professional peers. Having voiced my misgivings, I published them subsequently in an academic peer-reviewed journal: my article replicated the method of Findings 204 on data from our own consortium's research, and compared its conclusions, case-by-case, with those based upon our own methods, with a much less favourable prognosis for the RBI than the Minister's, to say the least (Hope, 2004). The bases of each method were also discussed and the results compared. Following a protracted review process, an online-only report of our evaluation was finally published by the Home Office, unchanged, over a year after the Minister's announcement (Hope et al., 2004). Trustingly, we had left the selection of a title to the Home Office, though the one the officials chose - Strategic Development Projects in the Yorkshire and the Humber, East Midlands and Eastern Regions - unlike those chosen for the other consortia's reports, seems quite a good way of 'burying bad news', at least from the gaze of Internet search engines. 
Hope, T. (2008). 'The first casualty: evidence and governance in a war against crime'. In P. Carlen (Ed.) Imaginary Penalities. Cullompton, Devon: Willan. ISNB 978-1-84392-375-6; pp. 45-63. (C) The editor and contributors.

Some while later, I published a similar, perhaps more accessible, account of the disagreement with the Home Office in an article for the journal Criminal Justice Matters, which also voiced some concerns about the way in which the Home Office assessed crime trends for performance purposes (Hope, 2006). This was submitted in May 2006 as part of the written evidence of the Centre for Criminal Justice Studies to the House of Commons Science and Technology Committee Enquiry into Scientific Advice to Government (STC, 2006, Ev 145), to which I also gave evidence in person (STC, 2006, Ev 38). The publication of the Committee's report (STC, 2006) evoked concern in the media. Thus The Guardian (Wednesday November 8, 2006) headlined its coverage with "...MPs accuse Ministers of twisting science for political purposes: evidence distorted to give fig leaf of respectability". Gratifyingly, we, the social scientists, had been accepted as purveyors of truth, both by Parliament and the Press.

Yet, the nature and grounds for the disagreement between our findings and those of the Home Office are not so simple. Particularly, they cannot, or ought not to, be accepted on teleological grounds alone. Just because Ministers have 'political purposes' in accepting some kinds of evidence, and rejecting others, does not in itself damn the evidentiary basis of their selectivity and bestow righteousness upon our own. After all, despite the cant, politicians only act politically, and that is what the electorate expects, so long as they stick by the rules and principles of democratic trust. Instead, what I hope to suggest in this chapter is that a much more pernicious process had been at work: namely, an effort involving the collusion of the 'official' social science community within, and closely associated with, government to 'fix' the bases and criteria upon which 'evidence' for policy and practice would be constructed in order to bias results in favour of politically-congenial outcomes. And this comprised the basis of our disagreement with the Home Office.

Yet, the constitutional imaginary of ministerial responsibility should equally not be taken literally as a convenient fiction whereby Ministers appear to be personally cognizant of the operations of their officials - such a fiction is collusively selfserving of both politicians and theorists alike, particularly those of the latter persuasion who wish to denote super-ordinate powers to 'the State', that any empirical, institutional-political account of policy-making ought instantly to dispel (see, Rock, 1990; Windlesham, 1993). However, like the general public itself, and despite the rise of the Junior Minister as a departmental micro-manager (another consequence of the new public management - see Rhodes, 1997), ministers still have to trust their officials in the governance of their departments. In fact, although our own side of this particular disagreement has remained constant, that of the official side has not. The true history, and explanation, of the events surrounding the evaluation of the CRP lies within the interstices of the New Labour Governments over the period. Yet while collective cabinet responsibility and the political subservience of civil servants also remain convenient constitutional imaginaries, it would appear that, in the demise of the CRP, there had been a general falling-out between Ministers, on the one hand, and Home Office officials (particularly the researchers), on the other, with the latter seeking to put their own spin on the proceedings (Davies, 2003). In what follows, it is apparent that all sides of the disagreement about 'evidence' and the CRP are not just concerned about selectivity of data but disagree about the epistemology of the evidence itself. And to prosecute such a disagreement necessarily 
Hope, T. (2008). 'The first casualty: evidence and governance in a war against crime'. In P. Carlen (Ed.) Imaginary Penalities. Cullompton, Devon: Willan. ISNB 978-1-84392-375-6; pp. 45-63. (C) The editor and contributors.

requires constructions of the 'imaginary' as well as the 'real' on all sides of the conflict.

\section{$\underline{\text { Evidence-Based Policy and Practice }}$}

Under the leadership of its first Home Secretary (Straw), New Labour put in place conceptual apparatus that would, in practice, stack the odds in favour of coming up with success. Central to this endeavour would be the co-option of social science into the machinery of governance of crime reduction. The over-arching rubric was to be that of Evidence-Based Policy and Practice (EBPP). New Labour's successful election pitch to be the better managers of crime than the incumbent Conservatives alongside a buy-in to the prevailing rhetoric of the 'New Public Management' (NPM) - meant that the Labour Government of 1997 was susceptible to a seemingly rational, business-like approach to crime prevention - already being practised by the Conservatives (Hope, 2005) - as its own goal, albeit re-branded as Crime and Disorder Reduction (Home Office, 1999). In order to identify crime prevention priorities, targets and methods, the recommended approach should be to conduct a 'crime audit' or 'crime profile', primarily based on statistical data. Concerning the framing of prevention strategies, the approach would ignore not just local professional agency expertise and practice but also most forms of political intelligence in favour of a new information-based, expert technology of decision-making. This emerging "what works" 'knowledge-base' would direct both noviciate local authorities and the professional police - who were to be brought into formal partnership by the Crime and Disorder Act (1998) - apparently towards a more scientific, yet 'realist', approach to crime control (Goldblatt and Lewis, 1998).

In contrast to the "nothing works" message perceived as stemming from much previous social scientific evaluation research, newer, practically-oriented 'crime sciences', emerging from the Home Office Research, Statistics and Development Directorate (RDS), were now promising useful and applicable techniques for the utilisation of information-based intelligence for policing, crime prevention and offender-management programmes within the community (Tilley and Laycock, 2000). Not surprisingly, on gaining office after 18 years in opposition, and with manifesto pledges to deliver, New Labour Ministers would be highly susceptible to a technology that not only promised to hand them the prize of crime reduction, and was consistent with the performance-oriented NPM that they saw as central to their 'modernising agenda', but also would give a politically incontrovertible aura (because it was rational and scientific) to the otherwise muddling and uncertain reality of crime prevention; thereby redeeming their electoral hostage to fortune, while constructing a non-ideological criterion of accountability - that which "works".

Statistics and research findings have played a central role in this endeavour. Thus, ten years later, the Home Office RDS Directorate was still describing itself as providing:

“...information, research and statistics on topics that relate to Home Office responsibilities such as crime, the justice system and immigration. Home Office ministers and policy-makers, who need to make decisions based on evidence, then use these research findings and statistics to inform their 
Hope, T. (2008). 'The first casualty: evidence and governance in a war against

crime'. In P. Carlen (Ed.) Imaginary Penalities. Cullompton, Devon: Willan. ISNB

978-1-84392-375-6; pp. 45-63. (C) The editor and contributors.

decisions (http://www.homeoffice.gov.uk/science-research/RDS/ ; accessed 3/04/2007, emphasis added).

It goes on, in rather elementary fashion, to describe

“...how we use research to make policies...For example, by accurately measuring burglary levels over time we can find out whether our burglaryreduction strategies are working or not: if we found levels of burglary were dropping, we could develop the successful strategies further; if we found levels stayed the same or increased then that would be evidence that our antiburglary strategies weren't working, so we would then change and improve them." (ibid.)

Aside from a dubious faux-naiveté, this is false, or imaginary, in two respects: first, clearly, as a depiction of the realities of policy-making and practical decision-making; but second, as an uncritically realist depiction of the evidentiary political process that was actually followed by the Home Office during this period. In this respect, the above statement is as much a deception about the Home Office attitude towards 'evidence' as it is about the use of 'evidence' in policy-making.

\section{$\underline{\text { Jack-in-the-Box }}$}

Periodically, the Home Office RDS has invested in statistical analysis to forecast trends in crime and punishment. Obviously, since we have no information on the future, forecasts are projections based upon prior, known information. In policyanalysis, they serve not in any mystic way but as an hypothetical or counter-factual that is, an 'imaginary' projection of what would happen if what may be about to happen were not to happen. Such projections are of greatest value retrospectively, since we can then assess what actually had happened against our estimate of what might have happened, had what happened not happened. Many applications of the techniques of econometric time-series forecasting are concerned with estimating reliable counter-factuals based on past performance to be used to assess the actual performance of policy interventions. The explanatory, causal role of counter-factual reasoning finds its best (imaginary) representation in Dickens' A Christmas Carol or Capra's film It's a Wonderful Life (1946). Just as Scrooge and George Bailey, respectively, are brought to appreciate the value of their lives by virtue of ghostly and angelic devices that project visions of a present and future without them, statistical modelling in policy analysis is intended to achieve the same effect.

Ironically, the first effort at what in later years was to become known as the 'Home Office model' - a statistical model of the long-term crime trend - was carried out below the political horizon by the then Home Office Research and Planning Unit (Field, 1990). When brought subsequently to his attention by the media, it caused considerable consternation to the Home Office minister-of-the-day, largely because it suggested, contrary to Government thinking, that crime trends were susceptible to economic factors, over which his Government claimed to have some influence ${ }^{2}$. Since it implicated government economic policy as a cause of crime, the Labour Party in opposition had used the model as a stick to beat the Conservatives in its successful campaigning over crime. 
Hope, T. (2008). 'The first casualty: evidence and governance in a war against crime'. In P. Carlen (Ed.) Imaginary Penalities. Cullompton, Devon: Willan. ISNB 978-1-84392-375-6; pp. 45-63. (C) The editor and contributors.

One of New Labour's chief electoral pledges in 1997 was to put government spending itself upon a more rational, evidence-based footing. To that end, the Chancellor of the Exchequer initiated the first, triennial Comprehensive Spending Review (CRS), reporting in 1998. The CRS not only set out spending plans for the forthcoming period but also had required spending departments to estimate the need for the expenditure. Ostensibly, the substantial funds for the CRP were released on the basis of the case submitted by the Home Office ${ }^{3}$. The requirement to have the effect of the expenditure evaluated independently was part of the conditions of funding imposed by the Treasury (Homel et al., 2004). As part of its case, the Home Office produced a revision of its model of the crime trend: much of the post war period had seen sustained growth in the rate of crime, and until then the model seemed to produce a good fit to the trend(Field, 1999) ${ }^{4}$. However, forecasts based upon the model predicted, at best, a twenty-six per cent rise in burglary for the period 1998 to 2001 (Dhiri et al., 1999), projections emerging just at the time the Government was launching the Reducing Burglary Initiative (Home Office, 1999). This must have posed something of a dilemma for the Home Secretary: on the one hand, the forecast demonstrated the need for the RBI; on the other hand, if it turned out to be true, did not augur well for its prospects.

Undaunted, the Home Secretary, Jack Straw, set about making a virtue of the forecast's counter-factuality:

"... There is nothing inevitable about the trend in the model. Halfway through this period there is good evidence we are in fact bucking the projected trend. Burglary in the first two years of this period is down, not up; and vehicle crime is down, not up. This research therefore underlines the relative success achieved so far, but also the scale of the challenge we must face." (Quoted in The Guardian, Tuesday November 30, 1999).

As The Guardian helpfully went on to explain (presumably steered by the Home Office Press Office):

"...The resulting projections are based on a forecast of what will happen if current demographic and economic trends continue without any impact from crime reduction measures taken by the police and the government". (Emphasis added.)

Disingenuously, however...

"...officials said the last two years [i.e. since the election in 1997] had seen property crime fall by $12 \%$ when their model predicted it would rise by $6 \% "$

This conveniently over-looked the fact that crime trends, including burglary, had been declining since around 1995, prior to Labour gaining office (Walker et al., 2006, Figure 6.2), in effect giving the Home Office four years worth of confidence in their trend-bucking assertions, while also inserting a new, politically advantageous Year Zero into the trend. Even more advantageously, the briefing suggested that this was: 
Hope, T. (2008). 'The first casualty: evidence and governance in a war against crime'. In P. Carlen (Ed.) Imaginary Penalities. Cullompton, Devon: Willan. ISNB 978-1-84392-375-6; pp. 45-63. (C) The editor and contributors.

"... an indication that the historic link between crime and the economy might be breaking down." 5

Be that as it may, how convenient would that possibility be for a Crime Reduction Strategy consisting primarily of deterrent, support and control measures aimed at individual victims and offenders (Home Office, 1999)? So, we have the Home Secretary offering a political wager. Yet unlike previous governments' hostages to fortune (Downes and Morgan, 1994), this time he had taken the trouble not only to calculate the odds but also to set-up the terms of the wager. And he seemed to have won his bet with the electorate - residential burglary recorded by the police declined by around 20 per cent (Walker et al., 2006, Table 2.04) during this specific period. Since 1995 there has been a 62 per cent decline in burglary reported to the British Crime Survey (Walker et al., 2006, Table 2.04); ergo, a tremendous government success, contributing to a favourable climate that produced two further election victories.

\section{Sauce for the Goose is sauce for the Gander}

Just as the Home Office had engaged in counter-factual reasoning, so too did we in our effort to evaluate the impact of a number of the pilot Strategic Development Projects (SDPs) of the RBI. Details of how we measured project impact and the specific methods of our statistical (time-series) evaluation model are contained in Hope et al. (2004) $)^{6}$. The grounds for the divergence between our results and those of the Home Office (Kodz and Pease, 2003) are published in Hope (2004). But why was it that the Home Office felt so compelled to repudiate our results? A clue is contained in the implications of our analysis, as set out in Table 1 (from Hope et al., 2004). Column A lists the percentage change in the number of burglaries per month occurring in each of the SDP's target areas during the period that they were in receipt of the first-phase of Home Office funding. Column B provides an estimate of the change in burglary that our methods suggested could be attributed solely to the specific, measured outputs of each of the SDPs. This is a hypothetical estimate provided by our model of what would have been the impact of the project alone, net of all the other changes going on in each area that would have affected the areas' observed burglary rate (Column A). So, by subtraction, Column $\mathrm{C}$ represents an estimate of the contribution of all these other things, net of the project. In our statistical model, the test of significance of the estimate of change attributable to the project is evaluated by comparing an estimate of the change that might be due to our measure of project impact (our designated 'factual') against a projection of the trend prior to the initiation of project activities, net of the impact of the project. This is the total of 'counter-factual' possibilities, of which the residual change (Column C) is an alternate, observed 'factual' representing the influence of all the other (counterfactual) things that were not produced specifically by the factual projects.

\section{Table 1 about here}

Despite burglary declining in all but four of the twenty project areas studied, there was 'tremendous' variation in the degree to which the reduction could be attributed to the project rather than to 'other things'. Some projects (mostly in Group A) appeared to be out-and-out successes, apparently dominating the trend and reducing burglary in 
Hope, T. (2008). 'The first casualty: evidence and governance in a war against crime'. In P. Carlen (Ed.) Imaginary Penalities. Cullompton, Devon: Willan. ISNB 978-1-84392-375-6; pp. 45-63. (C) The editor and contributors.

their areas. Other projects (mostly in Group C) also dominated their local burglary trend but in the opposite way, appearing to be making things worse (Group C), often despite what might have been an otherwise favourable downward trend. The remainder appeared to be battling against the impact of 'other things': sometimes heroically (seemingly keeping a rising tide of crime at bay), sometimes ineffectually, and sometimes negligibly. Fortunately, in the context of generally declining crime rates, such 'failures' might be over-looked. But all these local struggles were smoothed over by the officials' method (Kodz and Pease, 2003) which, in all cases where our results disagreed, attributed observed changes to the effect of the projects, rather than attributing them to the effect of other things (Hope, 2004). Unless the experience of our projects was totally different from those studied by the other consortia $^{7}$, then the same smoothing-over of local experience allowed the Minister the evidence needed to claim success overall, in anticipation of the remainder of the RBI to come.

\section{Wriggle room at the Home Office}

Of course, in the higher, political scheme, this kind of local detail probably does not matter very much, especially in a state such as the UK where power is highly centralised. If what counts for re-election purposes is a national reduction in crime, then it does not really matter how that came about; after all, government can always imply that it had a hand also in many of the 'other things' that could have brought about the crime drop. One obvious escape route would be to attribute the national reduction in crime to the general impact of the government's economic and social policies, including its specific programmes for local regeneration and tackling social exclusion. But for the Home Office that would mean not only giving away a success to other ministries but also a restoration of the 'historic link' between crime and the economy, which it had sundered previously ${ }^{8}$. The Home Office also ventured another imaginative way of wriggling out of the problem by claiming that substantial reductions could be attributed to an anticipation of benefits effect (Smith et al., 2002), whereby observed reductions locally were imagined to have been brought about by the mere announcement that crime prevention activity was about to take place, presumably scaring away the local burglars. ${ }^{9}$ Unfortunately, the evidence put forward in support of this fancy (Bowers and Johnson, 2003) is as flawed as the methodology employed to support it (Hope, 2004; Hope et al., 2004).

In any event, Home Office officials had sold the idea of the CRP as a set of locallybased, practical crime prevention projects (Homel et al., 2004) specifically intended to find out and implement 'what works, for whom, and in want circumstances'. Certainly, all the Strategic Development Projects had had their plans inspected, revised and approved by a group of Home Office consultants prior to being granted funds (Tilley et al., 1999). However, with evidence mounting of massive and widespread implementation difficulties, certain Home Office officials, their associates and consultants, evidently started to brief against the ministerial line, especially that of the Treasury. Strangely, at the same time as officials seem to have been briefing the Minister about the tremendous success of the RBI, they were also telling The Guardian journalist Nick Davies about how ministerial actions had undermined the likelihood of success of their Crime Reduction Programme (Davies, 2003). 
Hope, T. (2008). 'The first casualty: evidence and governance in a war against crime'. In P. Carlen (Ed.) Imaginary Penalities. Cullompton, Devon: Willan. ISNB 978-1-84392-375-6; pp. 45-63. (C) The editor and contributors.

The essence of their critique was repeated in a subsequent, supposedly objective, review of the implementation of the CRP (Homel et al., 2004). One of their central arguments is that the aspiration of the CRP to be an experimental exercise in EBPP was countermanded by Ministers (obviously for political purposes), who shifted projects away from being experiments towards being expected to reduce crime, also shifting the management of the CRP away from the evidence-based crime prevention professionals at the Home Office, who were prevented from having a hands-on, directive involvement with local projects. It was further alleged that, following Treasury guidelines, Home Office officials had been instructed (against their wishes) to advise the independent consortia hired as evaluators not to provide projects with evidence on their progress. Thus, local projects were denied an opportunity to find out how they were doing, could not adjust their implementation plans in the light of initial difficulties, and so were not able to deliver anticipated crime reduction. The implicit argument is that had the CRP management access to the progress of projects, and had the local projects access to information in a timely fashion, the apparently massive implementation failure of the CRP could have been avoided (see Bullock and Tilley, $2003)^{10}$. Still, although plausible, and certainly self-serving, this excuse has another great advantage as an 'imaginary': since it is post hoc ergo propter hoc fallacious, it cannot be put to the test.

Nevertheless, from a contracted evaluator's perspective, this line is also factually untrue. I would imagine that all evaluators' contracts had required them, as our's did, to evaluate process as well as impact, but I do know that we were obliged to provide regular project monitoring evidence to the Home Office (including costs and use of resources) from an early stage. Indeed, it almost seemed that our purpose, as our contract managers appeared to interpret it, was primarily to collect data that would be fed into their own analysis - as indeed happened publicly with Findings 204 (Kodz and Pease, 2003; see also Hamilton-Smith, 2004). Importantly, right from the start we were obliged to collect monthly totals for the number of burglaries recorded in the target areas for each of the projects, sending these each quarter as a return to our Home Office research managers - two of whom were also the authors of Homel et al. (2004). Further, arrangements for project accountability were also in place throughout via the regional Government Offices. Thus, Home Office programme managers (and presumably Ministers) did have feedback on the implementation of the CRP from an early stage, and did have an inclination about the reality of how the projects were working.

Questions then arise as to what was done with this early evidence, and what its impact was on the management and progress of projects and the CRP itself: to what extent did Home Office officials feed this information back to projects, and did this information have any effect - if not, what then accounts for implementation failure? Notwithstanding whether Minister's expectations of the CRP were realistic (nor how they might have formed these expectations), how did Home Office officials themselves react to the 'evidence' that many aspects of their programme were facing major difficulties? Crucially, did their advice on the early evidence of implementation difficulties, assuming it was given, have an effect on subsequent Ministerial decisions? Indeed, we do know, from the report of The Guardian journalist Nick Davies in 2003 (Davies, 2003), that the decision to devolve management of the remainder of the CRP to newly-appointed Crime Reduction Directors, based in the 
Hope, T. (2008). 'The first casualty: evidence and governance in a war against crime'. In P. Carlen (Ed.) Imaginary Penalities. Cullompton, Devon: Willan. ISNB 978-1-84392-375-6; pp. 45-63. (C) The editor and contributors.

regional government offices, was taken in this context. So, was this a political move by Home Office Ministers to wriggle off the hook of the CRP; and, far from bucking the trend, was this an effort to pass the buck to the hapless local projects, via their regional Crime Reduction Director patsies? Or is that another teleological account of political purposes?

\section{Shooting the Messenger}

Finally, when all else fails, why not resort to that well-known practice of shooting the messenger? A convenient and revealing means of recounting this process is provided by reference to a Home Office email correspondence of 9-15 August 2006: the subject matter is entitled "RE: Politics of Criminological Research" which appears to have been prompted by the submission of a "draft chapter" by its authors, whom we shall call $\mathrm{X}$ and $\mathrm{Y}^{11}$. In the correspondence with $\mathrm{X}$ and $\mathrm{Y}$ that occurred three months after I had given my evidence to Parliament, officials said, with reference to Findings 204:

“...It was important that the results from the three RBI consortia were brought together and Ken (sic) undertook an analysis using a standard shift-share analysis, which is the norm for evaluations of this kind. The findings were subject to our usual peer review processes. I have to say that I find it astounding that the authors [i.e. $\mathrm{X}$ and $\mathrm{Y}$ ] casually describe work by a person of...eminence as the 'Home Office mounting a re-analysis which managed to turn failure into success" ". 09 August 2006 3:12 PM (emphasis added).

With regard to our own research, the officials said:

“...This [i.e. our time-series method] is a non-standard method, and one which differed from the solution adopted by the other two consortia [involved in evaluating the RBI-Phase 1]...We also had other external advice that suggested Tim's time-series method was weaker...Tim may not like that conclusion...Coupled with the independent advice we received from a range of sources, I do not think it is fair to repeat Tim's accusations as if they have credibility". 10 August 2006 6:10 PM (emphasis added).

Until I had sight of this correspondence I was unaware of the existence of this particular piece of external advice; nor in the course of drafting Hope et al. (2004) were we appraised of it; nor, needless to say, were we offered an opportunity for scientific rebuttal. Neither, if this is its view, has the Home Office sought publicly to counter the credibility of my evidence to the House of Commons, either at the time when the STC would have been able to take evidence, or in the Government's Response to the Committee's Report (STC, 2007). Presumably, then, confident in the eminence of its own appointed experts, Home Office officials remain privately dismissive not only of our own, apparently more humble, scientific acumen but also of the credulity of the House of Commons.

Nevertheless, Home Office confidence in its own expert advisors might be misplaced. It was as surprising to see time-series analysis regarded as a non-standard method of programme evaluation (cf. McCain and McCleary, 1979) as it was to see 'shift-share' analyses described as standard. For instance, there is no reference to this latter method 
Hope, T. (2008). 'The first casualty: evidence and governance in a war against crime'. In P. Carlen (Ed.) Imaginary Penalities. Cullompton, Devon: Willan. ISNB 978-1-84392-375-6; pp. 45-63. (C) The editor and contributors.

in either the Green Book (H.M. Treasury, no date) or the Magenta Book (Policy Hub, no date) - the standard official handbooks of policy appraisal methods intended to guide government research. Although not perhaps entirely imaginary, 'shift-share' analysis does not appear to be part of the standard official repertoire of policyevaluation methodologies. Rather, the method resembles a form of "change score analysis', an approach that is considered to be "notoriously unreliable" (Judd and Kenny 1981: 123-124). Evidently though, it must have been thought sufficiently reliable to be used in the published Home Office report on the overall costeffectiveness of the RBI-Phase 1 projects (Bowles and Pradiptyo, 2004) - again applied to our consortium's data against our wishes.

\section{The diminution of the love of truth}

The techniques used by Home Office officials described here seem a good example of those discussed by Thomas Matthiesen (2004): while overt repression of opposition is unacceptable in a democracy, there are nevertheless ways in which government can set about the 'silent silencing' of criticism. A particularly sophisticated way of doing this is to promulgate evidence-based policy criteria, and then to manipulate not only the evidence employed but also its epistemology. The relationship between science and politics uncovered here stands in contrast to that famously proposed by Donald $\mathrm{T}$. Campbell (1969). For Campbell, the value of the relationship lay in maintaining the autonomy of the two spheres of science and politics, precisely to preserve the overarching value of accountability to the public interest that ought to govern practice in either sphere. In Campbell's view, the danger inherent in too close a coupling of science and politics resides in a powerful imperative:

"...it is one of the characteristics of the present situation that specific reforms are advocated as though they were certain to be successful. For this reason, knowing outcomes has immediate political implications...if the political and administrative system has committed itself in advance to the correctness and efficacy of its reforms, it cannot tolerate learning of failure" (Campbell, 1978, p. 80; original emphasis).

For Campbell, the great threat was the trapped administrator - those officials (elected or appointed) who are unable to resist the temptation to use political authority to manipulate the evidence they present in public to produce a more tolerable valuation. Why Campbell was committed to developing an autonomous scientific approach to policy evaluation was that he foresaw a time when officials would become sufficiently adept in the manipulation of methods as to render it impossible for the electorate to assess their claims without the aid of counter-expertise. With EBPP, it would seem that time has come. Furthermore, since this imperative has not abated, trapped administrators may now feel sufficiently emboldened to go on the offensive to counter-attack the independent counter-expertise that resides in the Academy - at first in silence but also complicit with those 'quisling criminologists' who are prepared to do their master's bidding (Hope, 2008).

As Ulrich Beck argues in his vision of the Risk Society (Beck, 1992), the more relevant systematic intelligence has become in shaping and governing social life, the more that scientific rationality (the authority for such intelligence) has become a form 
Hope, T. (2008). 'The first casualty: evidence and governance in a war against crime'. In P. Carlen (Ed.) Imaginary Penalities. Cullompton, Devon: Willan. ISNB 978-1-84392-375-6; pp. 45-63. (C) The editor and contributors.

of governance. But governance does not supplant politics. So, as science comes to shape politics, it becomes itself a site for politics, losing its monopoly as a unitary method, and opening up opportunities for the legitimization of contending methodologies and epistemologies about the nature of science, its conduct and its criteria of validity. As political life becomes scientized, and vice versa, the structures of authority in each of the spheres loose their autonomy; science can now legitimately guide politics, but quid pro quo politics now has a say in science - what it endorses, what it encourages and how that which it supports is to be conducted. The value of science ceases to be derived from its methodology alone and is now also to be derived from its promise of utility.

The emergence of the regulatory state (Braithwaite. 2000), of which New Labour's strategy for the governance of crime would seem a good example, further problematises the epistemology of evidence, since not only politics but now also public administration comes to rely upon scientized evidence, notably in the shape of EBPP. Yet again, far from avoiding politics in some imaginary world in which regulation and accountability become subsumed into technical expertise, the short-run political advantages to be gained from EBPP may rebound upon those who seek to profit by it, for as Jasanoff remarks:

"...if it is seen that science cannot provide definitive answers to questions about risk, then policy-makers cannot fall back on unassailable technical justifications for their regulatory choices" (Jasanoff, 1987: 225)

Yet it would seem that the policy-makers' answer would be to make sure that science is indeed seen publicly to be providing definitive answers. Nevertheless, since recourse to the imaginary (hypothetical, counter-factual) is a method by which science evaluates its own evidence, to engage with scientific evidence so as to eradicate its indeterminacy and contestability paradoxically involves imposing, instead, a political imaginary, including a 'politicizing' of scientific methodology.

Some ways of regulating disputes and resolving conflicts about scientific evidence take place in public. In the regulatory state, one mode is to treat scientific evidence like other forms of public evidence, subjecting disputes ultimately to the scrutiny of the courts or other quasi-judicial regulatory bodies (Jasanoff, 1987). For scientific communities themselves, the institutions of peer review aim to serve a self-regulatory purpose; offering a public guarantee as to the reliability of the evidence produced, and a guide to the grounds upon which disputes subsist ${ }^{12}$. However, the calamitous imagery of warfare provides government with the excuse it may need for evading public scrutiny: allowing it the right to abrogate the public interest to its own, to select information for the greater good, and to construct its evidence in secret. In his Godkin Lectures at Harvard University, nearly half century ago at the height of the Cold War (though referring to certain calamitous science-based decisions of the previous global conflict, including the 'carpet-bombing' of German cities) C. P. Snow said that:

"...almost all secret scientific choices are something like pure closed politics." $\left(\right.$ Snow 1961: 56) ${ }^{13}$ 
Hope, T. (2008). 'The first casualty: evidence and governance in a war against crime'. In P. Carlen (Ed.) Imaginary Penalities. Cullompton, Devon: Willan. ISNB 978-1-84392-375-6; pp. 45-63. (C) The editor and contributors.

Away from public gaze, decision-making is shaped by the habitus of government bureaucracy: where skill in committee, the inertia of decision-making, and the efficacy of what Snow called court politics (having the ear of the minister) all predominate; and where players adept at their manipulation, or servile to their protocols, can command attention and influence. As Snow suggests, such conditions give greater rein to certain kinds of science, and scientist, than to others. Though it remains moot as to whether it is the politician that influences the scientist, or vice versa, it would seem that the imaginary of secret scientific warfare that evidently still pervades government science, nevertheless has real consequences, for both politics and science. 
Hope, T. (2008). 'The first casualty: evidence and governance in a war against crime'. In P. Carlen (Ed.) Imaginary Penalities. Cullompton, Devon: Willan. ISNB 978-1-84392-375-6; pp. 45-63. (C) The editor and contributors.

TABLE 1

IMPACT OF PROJECTS ON BURGLARY

\begin{tabular}{|l|c|l|l|}
\hline & $\begin{array}{l}A \\
\text { Change in } \\
\text { Target Area } \\
\text { Project }\end{array}$ & $\begin{array}{l}B \\
\text { Change in } \\
\text { Target due } \\
\text { to Project } \\
\text { (modelled) }\end{array}$ & $\begin{array}{l}\text { Other } \\
\text { change in } \\
\text { Target } \\
\text { (A-B) }\end{array}$ \\
\hline Group A & & & \\
\hline A1 & -36 & $-49^{*}$ & 13 \\
\hline A2 & -40 & $-43^{*}$ & 3 \\
\hline A3 & -47 & $-37^{*}$ & -10 \\
\hline A4 & -3 & $-35^{*}$ & 32 \\
\hline A5 & -29 & $-27^{*}$ & -2 \\
\hline A6 & -20 & $-4 *$ & -16 \\
\hline Group B & & & \\
\hline B1 & -40 & -27 & -13 \\
\hline B2 & -42 & -21 & -21 \\
\hline B3 & -24 & -20 & -4 \\
\hline B4 & -2 & -15 & 13 \\
\hline B5 & 13 & -10 & 23 \\
\hline B6 & -32 & -7 & -25 \\
\hline B7 & -37 & -6 & -31 \\
\hline Group C & & & \\
\hline C1 & -47 & 4 & -43 \\
\hline C2 & -16 & 6 & -10 \\
\hline C3 & -36 & 6 & -42 \\
\hline C4 & 29 & 11 & 18 \\
\hline C5 & -14 & 12 & -26 \\
\hline C6 & 13 & 34 & -22 \\
\hline C7 & 14 & $39^{*}$ & -25 \\
\hline & & & \\
\hline
\end{tabular}

$*=$ significant at p. <.05.

From: Hope et al., 2004. 
Hope, T. (2008). 'The first casualty: evidence and governance in a war against crime'. In P. Carlen (Ed.) Imaginary Penalities. Cullompton, Devon: Willan. ISNB 978-1-84392-375-6; pp. 45-63. (C) The editor and contributors.

References

Beck, U. (1992). Risk Society. London: Sage Publications.

Bowers, K.J. and S. D. Johnson (2003). The Role of Publicity in Crime Prevention: findings from the Reducing Burglary Initiative. Home Office Research Study 272. London: Home Office Research, Development and Statistics Directorate.

Bowles, R. and R. Pradiptyo (2004). Reducing Burglary Initiative: and analysis of costs, benefits and cost effectiveness. Home Office Online Report 43/04. London: Home Office.

Braithwaite, J. (2000). The New Regulatory State and the Transformation of Criminology. In D. Garland and R. Sparks (Eds.) Criminology and Social Theory. Oxford: Oxford University Press.

Bullock, K and N. Tilley (2003) (Eds.). Crime Reduction and Problem-oriented Policing. Cullompton, Devon: Willan Publishing.

Campbell, D.T. (1969). 'Reforms as experiments'. American Psychologist, 24, 40929.

Campbell, D.T. (1978). 'Reforms as experiments'. In J. Bynner and K.M. Stribley (Eds.) Social Research : Principles and Procedures. Oxford: Oxford University Press.

Cook, T.D. and D. T. Campbell (1979) Quasi-Experimentation. Boston, MA.: Houghton Mifflin.

Judd, C.M. and D. A. Kenny (1981). Estimating the Effects of Social Interventions.

New York: Cambridge University Press.

Davies, N. (2003). 'Using new tools to attack the roots of crime'. The Guardian, 12 July 2003.

Dhiri, S., S. Brand, R. Harries and R. Price (1999). Modelling and Predicting Property Crime Trends in England and Wales. Home Office Research Study 199. London: Home Office.

Downes, D. and R. Morgan (2002). 'The skeletons in the cupboard: the politics of law and order at the turn of the Millennium'. In M. Maguire, R. Morgan and R. Reiner (Eds.). The Oxford Handbook of Criminology. Third Edition. Oxford: Clarendon Press.

Downes, D. and R. Morgan (1994). 'Hostages to fortune?: the politics of law and order in Post-War Britain'. In M. Maguire, R. Morgan and R. Reiner (Eds.). The Oxford Handbook of Criminology. Third Edition. Oxford: Clarendon Press. 
Hope, T. (2008). 'The first casualty: evidence and governance in a war against crime'. In P. Carlen (Ed.) Imaginary Penalities. Cullompton, Devon: Willan. ISNB 978-1-84392-375-6; pp. 45-63. (C) The editor and contributors.

Farrell, G. K. Bowers, S. Johnson and M. Townsley (Eds.) (2007). Imagination for Crime Prevention: Essays in honour of Ken Pease. Crime Prevention Studies, Vol 21. Devon: Willan Publishing/Criminal Justice Press, New York.

Field, S. (1999). Trends in Crime Revisited. Home Office Research Study 195. London: Home Office.

Field, S. (1990). Trends in Crime and Their Interpretation: a study of recorded crime in post-war England and Wales. Home Office Research Study 119. London: HMSO.

Goldblatt, P. and C. Lewis (1998) (Eds.) Reducing Offending: an assessment of research evidence on ways of dealing with offending behaviour. Home Office Research Study 187. London: Home Office.

Hamilton-Smith, N. (Ed.) (2004). The Reducing Burglary Initiative: design, development and delivery. Home Office Research Study 287. London: Home Office.

HM Treasury (no date). 'Green Book, Appraisal and Evaluation in Central Government http://greenbook.treasury.gov.uk/ (accessed 14/12/07).

Home Office (1999). The Government's Crime Reduction Strategy. London: Home Office.

Homel, P., S. Nutley, B. Webb and N. Tilley (2004). Investing to Deliver: reviewing the implementation of the UK Crime Reduction Programme. Home Office Research Study 281. London: Home Office.

Hope, T. (2008). 'A firing squad to shoot the messenger: Home Office peer review of research'. London: Centre for Crime and Justice Studies.

Hope, T. (2006). 'Things can only get better'. Criminal Justice Matters. No. 62 Winter 2005/06 http://www.kcl.ac.uk/depsta/rel/ccjs/cjm62.html .

Hope, T. (2005). 'The new local governance of community safety in England and Wales'. Canadian Journal of Criminology and Criminal Justice, 47 (2), 367-387

Hope, T. (2004). 'Pretend it works: evidence and governance in the evaluation of the Reducing Burglary Initiative'. Criminology and Criminal Justice, 4 (3), 287-308.

Hope, T., J. Bryan, E. Crawley, P. Crawley, N. Russell and A. Trickett (2004). Strategic Development Projects in the Yorkshire and the Humber, East Midlands and Eastern Regions. Home Office Online Report 41/04. London: Home Office. http://www.homeoffice.gov.uk/rds/onlinepubs 1.html

House of Commons Science and Technology Committee (2004). Scientific Publications: free for all? Tenth Report of Session 2003-04. Volume 1: Report. The House of Commons: HC 399-1. 
Hope, T. (2008). 'The first casualty: evidence and governance in a war against crime'. In P. Carlen (Ed.) Imaginary Penalities. Cullompton, Devon: Willan. ISNB 978-1-84392-375-6; pp. 45-63. (C) The editor and contributors.

Jasanoff, S.S. (1987). 'Contested boundaries in policy-relevant science'. Social Studies in Science, 17, 195-230.

Judd, C.M. and D. A. Kenny (1981). Estimating the Effects of Social Interventions. New York: Cambridge University Press.

Kodz, J. and K. Pease (2003). 'Reducing Burglary Initiative: early findings on burglary reduction'. Findings 204. Research, Development and Statistics Directorate. London: Home Office.

Lewis, C. (Ed.) (2003). Modelling Crime and Offending: recent developments in England and Wales. Occasional Paper No. 80. Research, Development and Statistics Directorate, Home Office. London: Home Office.

McCain, L.J. and R. McCleary (1979). 'The statistical analysis of the simple interrupted time-series quasi-experiment'. In T.D. Cook and D. T. Campbell QuasiExperimentation. Boston, MA.: Houghton Mifflin.

Mathiesen, T. (2004). Silently Silenced: essays on the creation of acquiescence in modern society. Winchester, Hants.: Waterside Press.

Policy Hub (no date). Magenta Book: Guidance Notes on Policy Evaluation. http://www.policyhub.gov.uk/magenta_book/ (accessed 14/12/07).

Rhodes, R.A.W. (1997). Understanding Governance. Buckingham: Open University Press.

Rock, P. (1990). Helping victims of crime : the Home Office and the rise of victim support in England and Wales. Oxford : Clarendon, 1990.

Smith, M.J., R.V. Clarke and K. Pease (2002). 'Anticipatory benefits in crime prevention'. In N. Tilley (Ed.) Analysis for Crime Prevention. Crime Prevention Studies, Volume 13. Monsey, NY: Criminal Justice Press.

Snow, C. P. (1961) Science and Government : the Godkin lectures at Harvard University, 1960. London : Oxford University Press, 1961.

STC (2007). Scientific Advice, Risk and Evidence Based Policy Making: Government Response to the Committee's Seventh Report of Session 2005-06. First Special Report of Session 2006-07, HC 307. The House of Commons, 21 February 2007.

STC (2006). House of Commons Science and Technology Committee. Scientific Advice, Risk and Evidence Based Policy Making, Seventh Report of Session 2005-06, Volume I Report HC 900-I; Volume II Oral and Written Evidence HC 900-I. The House of Commons, 26 October 2006. 
Hope, T. (2008). 'The first casualty: evidence and governance in a war against crime'. In P. Carlen (Ed.) Imaginary Penalities. Cullompton, Devon: Willan. ISNB 978-1-84392-375-6; pp. 45-63. (C) The editor and contributors.

Tilley, N. and G. Laycock (2000). 'Joining up research, policy and practice about crime'. Policy Studies, 21, 213-227.

Tilley, N., K. Pease, M. Hough and R. Brown (1999). Burglary Prevention: early lessons from the Crime Reduction Programme. Crime Reduction Research Series Paper 1.

Walker, A. C. Kershaw, and S. Nicholas (Eds.) (2006). Crime in England and Wales, 2005/06. Home Office Statistical Bulletin, 12/06. London: Home Office.

Windlesham, D.J.G. H. Baron, (1993) Responses to Crime (Vol.2, Penal policy in the making). Oxford : Clarendon Press. 
Hope, T. (2008). 'The first casualty: evidence and governance in a war against crime'. In P. Carlen (Ed.) Imaginary Penalities. Cullompton, Devon: Willan. ISNB 978-1-84392-375-6; pp. 45-63. (C) The editor and contributors.

Notes

1 The Home Office obliged by removing reference to our consortium from the Acknowledgements to Findings 204 (Davies, 2003).

2 When appraised of the implications of the model, at a press conference held by the minister (John Patten) to account for a recent rise in crime, he reacted, apparently impromptu, by disparaging the researcher (and hence the research) ad hominem, along the lines of 'isn't he the one that wears the earring' (for a full account see Brake and Hale, 1992). This was an 'imaginary' in another sense too because he wasn't (although another colleague was). Aspersions about attire seem to be part of the imagery constructed in British political life when it suits (as it were) to denigrate specialist expertise, viz:

Mr Glass: "...I remember in the Treasury the geekier economists were referred to as 'v-necks'. These were people who came to work in v-neck sweaters and obviously were not entirely reliable!" (STC 2006, HC 900-II, Q1003)

Professor Hope: "As I said, I served in what was once the Home Office Research and Planning Unit. It was not a directorate. I was certainly proud to be a geek or a v-neck and I may even have worn denim at some point during my career" (STC 2006, HC 900-II, Q1004).

3 Around $£ 250$ million for the initial Crime Reduction Programme, with an additional $£ 150$ million to support local CCTV installations (Homel et al., 2004).

4 As noted below, the subsequent behaviour of the crime trend in England and Wales has differed markedly from that predicted by the model. The scientific response would be to undertake further research to come-up with a better-fitting model that also accounts for the decline in officially-recorded crime rates over the past ten years (Hope, 2007; Lewis, 2003).

5 As just indicated, this had scarcely been acknowledged officially as an 'historic link' before it was sundered again.

6 While we introduced an innovative way of measuring specific project impact - the construction of a measure of the intensity of project impact using both qualitative and quantitative data - all the 'raw' data we had collected and used to construct our measure had been approved by, and carried out on instruction from, the Home Office RDS (see Bowles and Pradiptyo, 2004). Of course, our epistemology is 'realist' in the sense that it assumes that our measures validly represent a reality, net of measurement error itself.

7 The information that would allow an evaluation of this possibility remains in the hands of the Home Office, though it does not look likely (Bowles and Pradiptyo, 2004).

8 Members of the public have been told repeatedly through the media about the internal Labour Party conflict and competition between Tony Blair (the Prime Minister) and Gordon Brown (the Chancellor of the Exchequer). Within the imaginary of collective cabinet responsibility, it was alleged that some policy issues, such as crime, and some Ministries, such as the Home Office, were the fiefdom of the PM, while others, such as economic policy and the Treasury were those of the Chancellor. While it must remain a matter of speculation as to its reasons, the apparent tension between the Home Office and the Treasury over matters surrounding the governance of the CRP must remain an important part of the backdrop.

9 A book of essays published in honour of one of the originators of this idea is 
Hope, T. (2008). 'The first casualty: evidence and governance in a war against crime'. In P. Carlen (Ed.) Imaginary Penalities. Cullompton, Devon: Willan. ISNB 978-1-84392-375-6; pp. 45-63. (C) The editor and contributors.

entitled "Imagination for Crime Prevention" (Farrell et al., 2007).

10 The Home Office has not released information that would afford an assessment of the extent of this failure.

${ }^{11}$ A copy of this exchange has been released to me in response to a 'subject access request' under the provisions of the Data Protection Act, 1998. Information regarding the identity of individuals was 'redacted'. A fuller account of this correspondence is contained in Hope (2008).

12 I elaborate elsewhere on the concept of peer-review in relation to these events (Hope, 2008).

13 I am grateful to my colleague Philip Stenning for coming across Snow's book in a second-hand bookstore in New Zealand. 